\title{
Tolerant hardwood natural regeneration 15 years after various silvicultural treatments on an industrial freehold of northwestern New Brunswick
}

\author{
by Martin Béland ${ }^{1}$ and Bruno Chicoine ${ }^{2}$
}

\begin{abstract}
We examined applicability of various partial cutting systems in order to regenerate tolerant hardwood stands dominated by sugar maple (Acer saccarhum), American beech (Fagus grandifolia) and yellow birch (Betula alleghaniensis) on northern New Brunswick J.D. Irving Ltd. freehold land. Sampling of 1065 one- $\mathrm{m}^{2}$ plots in 31 stands managed by selection cutting, shelterwood method and strip or patch cutting and in six control stands allowed a 15-year retrospective study of natural regeneration in stands of low residual densities and with minimal soil disturbance and no control of competing vegetation. Beech regeneration was most abundant in the patch cuts, yellow birch in shelterwood stands and sugar maple in the selection system areas. Results suggest that initial stand conditions influence the composition of the regeneration more than the prescribed treatment. At the stand scale (a few hectares), sugar maple recruitment was positively influenced by its proportion in the initial stand, and negatively by the cover of herbs and shrubs. Yellow birch regeneration was mainly affected by shrub competition. At the plot $\left(1 \mathrm{~m}^{2}\right)$ scale, mineral soil and decayed wood substrates and ground-level transmitted light were determinant factors for yellow birch regeneration. Beech-dominated stands were likely to regenerate to beech. A dense beech sucker understory was promoted in harvested patches. Areas with dense understory of American beech, shrubs, or herbs require site preparation to reduce interference either before or at the time of partial cutting. Shelterwood seed cutting and selection cutting should leave a residual of $12 \mathrm{~m}^{2} / \mathrm{ha}$ and $17 \mathrm{~m}^{2} /$ ha respectively in seed trees uniformly distributed.
\end{abstract}

Keywords: silviculture, northern hardwoods, partial cuttings, natural regeneration, recruitment, Acadian forest

\section{RÉSUMÉ}

Nous avons étudié lapplication de coupes partielles pour régénérer les peuplements de feuillus tolérants dérable à sucre (Acer saccharum), hêtre à grandes feuilles (Fagus grandifolia) et bouleau jaune (Betula alleghaniensis), sur les terres privées de J.D. Irving $L t d$. au Nouveau-Brunswick. 1065 parcelles $\left(1 \mathrm{~m}^{2}\right)$ échantillonnées dans 37 peuplements sujets à des coupes partielles (jardinage, progressive, par bandes, par trouées) et témoin a permis un suivi sur 15 ans des conditions environnementales affectant la régénération. Ces dernières contrastaient peu entre les traitements, les densités résiduelles après coupe étaient faibles et aucun scarifiage ni contrôle de la végétation concurrente nả été effectué. Le hêtre régénérait plus abondamment dans les trouées, le bouleau jaune après coupes progressives et lérable à sucre après jardinage. Les conditions du peuplement influençaient davantage la régénération que le traitement sylvicole. À léchelle du peuplement, la régénération en érable à sucre était reliée positivement à sa proportion dans le peuplement résiduel, et négativement aux recouvrements arbustif et herbacé. À léchelle de la parcelle $\left(1 \mathrm{~m}^{2}\right)$, la régénération du bouleau jaune semblait inhibée par la compétition arbustive et stimulée par le couvert du sol minéral, le bois décomposé et la lumière. La composition des peuplements forts en hêtre était difficile à modifier. Les coupes par trouées ont stimulée sa reproduction végétative. Les parcelles denses en hêtre, arbustes et herbacées recquièrent une préparation de terrain. Les coupes densemencement et de jardinage devraient laisser respectivement $12 \mathrm{~m}^{2} / \mathrm{ha}$ et $17 \mathrm{~m}^{2} /$ ha en arbres semenciers bien distribués.

Mots clés : sylviculture, feuillus nordiques, coupes partielles, régénération naturelle, recrutement, forêt acadienne

\footnotetext{
${ }^{1}$ Faculté de foresterie, Université de Moncton, campus d'Edmundston, Edmundston, Nouveau-Brunswick E3V 2S8. Author to whom corresopondence should be sent. E-mail : martin.beland@umce.ca

${ }^{2}$ Division arboriculture, Ville de Montréal, 801 rue Brennan, $4^{e}$ étage, Montréal, Québec H3C 0G4.
} 


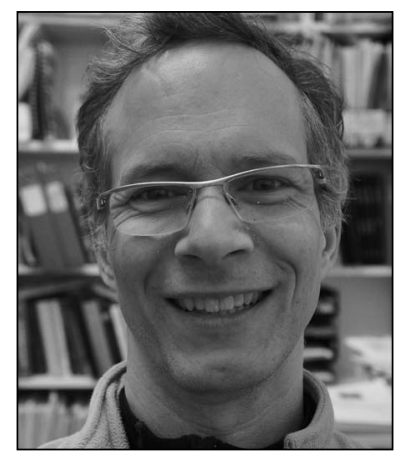

Martin Béland

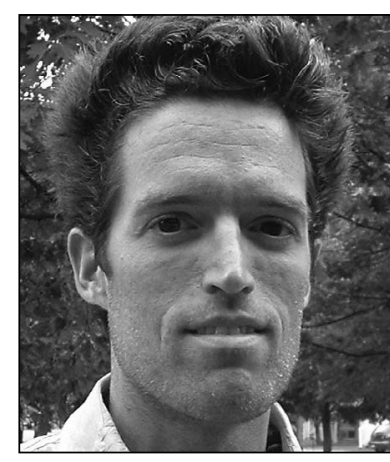

Bruno Chicoine

\section{Introduction}

Many scientists have studied regeneration in northern hardwood stands (Leak and Wilson 1958, Runkle 1982, Carson 1987, Beaudet and Messier 1998, Martin and Hornbeck 1990, Pacala et al. 1994, Beckage et al. 2000, Lepage et al. 2000, Leak 2005) because of its importance in forest dynamics (Runkle 1985, Ribbens et al. 1994) and productivity (Clark and Ji 1995, Hurtt and Pacala 1995).

In hardwood stands, partial cutting systems generally maintain the tolerant species composition (Leak and Filip 1977, Jenkins and Parker 2001, Angers et al. 2005) and favour sawlog quality production (Johnson 1984, Leak and Sendak 2002). Partial cuttings have variable effects on understory environmental conditions (Beaudet et al. 2002) and influence species composition of regeneration (Coates and Burton 1997). Four partial cutting treatments have been widely used in hardwood silviculture in Eastern North America for many years: selection cutting, shelterwood cutting, patch cutting and strip cutting.

Single-tree selection cutting is usually practised in highquality, uneven-aged tolerant hardwood stands and is characterized by small openings in the canopy ( 0.05 ha to 0.14 ha) which will eventually be filled in by advance regeneration and by residual tree crown expansion (Majcen and Richard 1992, 1995; Majcen 1995, 1996, 1997; Bédard and Majcen 2001, 2003). The avantages of selection cutting are numerous: 1) increase in annual volume increment of residual stems (Majcen 1995, 1996, 1997; Majcen and Richard 1995); 2) promotion of advance regeneration of shade-tolerant species, 3) acceptable sawlog yield; 3) maintenance of a forest cover essential to the good development of crop trees; 4) relatively short cutting cycles (Carson 1987); 5) maintenance of stand diameter structure (Mader and Nyland 1984); and 6) potential for quality regeneration in sufficient abundance for sustained yield (Miller 1995).

Another type of regeneration cutting is the uniform shelterwood method, performed by cutting $40 \%$ to $70 \%$ of the original basal area during the first entry (Hannah 1991). Under this system, the better mature trees are left distributed evenly throughout the stand to produce seed and provide partial shade for the advance regeneration. Residual trees are usually removed a few years later when regeneration is one metre high (Anderson et al. 1990, Hannah 1991). Micro-sites thus created are adequate for the germination of some species with increased light levels stimulating the growth of advance regeneration. Similar benefits may accrue from rehabilitation treatments leaving only widely spaced trees in high-graded stands with a merchantable basal area below $9 \mathrm{~m}^{2} /$ ha, or when basal area of trees $24 \mathrm{~cm} \mathrm{DBH}$ and larger is below $7 \mathrm{~m}^{2} / \mathrm{ha}$ (Anderson et al. 1990).

Patch cutting allows cutting of all trees in small groups or gaps of variable or fixed size ( 0.04 ha to $0.25 \mathrm{ha}$ ) more or less regularly spaced (Nyland 2002, Kelty et al. 2003). Environmental conditions vary with patch size, height of residual trees, and distance to edge. Importance of these small-size disturbances in the dynamics of unmanaged hardwood temperate forests is largely recognized (Runkle 1982). Studies on the regeneration in variable-size patches in northern hardwood stands (Goldblum 1997, Lessard et al. 1999, Beckage et al. 2000, Leak 2005) report a fair success of regeneration for shade-tolerant species present in initial stands, probably because patches offer conditions intermediate between selection cuttings and clearcuts. This cutting system promotes shade-intolerant or mid-tolerant species such as black cherry (Prunus serotina Ehrh.), yellow birch (Betula alleghaniensis Britt.), white pine (Pinus strobus L.) and white ash (Fraxinus americana L.).

Strip cutting consists of removing all trees from small linear and parallel strips of variable width, and increases light near the ground. With or without thinning in the retained strips, it constitutes a possible silvicultural option for the management of northern hardwoods in even-aged stands (Roberge 1987, Martin and Hornbeck 1990). Strips of $20 \mathrm{~m}$ to $60 \mathrm{~m}$ were more than $50 \%$ stocked with sugar maple regeneration after 14 years (Boivin 1985).

The effects of these partial harvests will vary with stand age at the time of harvest, time since last harvest, and the ability of species to disperse seeds over a distance. Stand age at the time of harvest affects species composition of post-harvest regeneration (Allison et al. 2003). Understory species composition, especially the abundance of later-successional species (Leak and Wilson 1958) and the quantity of dormant seed in the seed bank, change with stand age (Marks 1974, Tierney and Fahey 1998), but overall, structure and composition change with time. For example, the presence of large trees in a mature stand allows the production of massive amounts of seed (Ribbens et al. 1994).

Time since the last cut may have an impact on species composition of regeneration. Shade tolerance (Baker 1949, Burns and Honkala 1990) is commonly recognized as one of the main factors driving the dynamics of forest succession (Spurr and Barnes 1980, Shugart 1984, Kimmins 1997), and will influence survival at moderate and low light levels. Traditionnal classifications differentiate between the levels of shade tolerance (Baker 1949, Whitmore 1989, Burns and Honkala 1990) based on diameter and height increment as well as crown and tree shape (Spurr and Barnes 1980, Kimmins 1997). Recently, studies have attempted to empirically relate light availability with juvenile growth (Pacala et al. 1994, Wright et al. 1998) and radial growth with juvenile mortality (Buchman 1983, Buchman and Lentz 1984, Kobe and Coates 1997, Ward and Stephens 1997, Caspersen and Kobe 2001). Many authors have stressed the role of juvenile mortality in these processes (Lorimer 1981, Wright et al. 1998). Because yellow birch is less shade-tolerant, the probability of mortality with decreased light levels is higher. Many years after harvest, when forest cover tends to close and competition intensifies with the increased regeneration, densities of yellow birch seedlings tend to decrease especially in partially cut stands of moderate to high residual density (Gasser et al. 2010). 
The seed dispersal distance differs with species (Hoppes 1988, Johnson 1988) and may affect the regeneration success (Ribbens et al. 1994).

The present study compares the success of regeneration after various partial cuts performed in tolerant hardwood stands on industrial freehold land owned by J.D. Irving Ltd. in northwestern New Brunswick. Results have implications for future forest industrial operations in the Maritime provinces of Canada where a large portion of the forest land is composed of hardwood species.

The types of cuts studied are: strip, patch, shelterwood and single-tree selection cuts. Most of these were performed for over 15 years in the study area. We hypothesize that selection cutting and shelterwood cutting have less impact on light conditions and soil disturbance than strip or patch cuts, as a larger proportion of the forest cover is left in situ. Furthermore, these cuts were performed in winter, contrary to the strip and patch cuts, which create large openings and are usually carried out during the snow-free period of the year. For the same reasons, we hypothesize that strip and patch cuts will favour the regeneration of the less shade-tolerant species like yellow birch, whereas selection cutting should favor sugar maple and American beech. However, we assume that species composition of the regeneration will be strongly influenced by the parent trees and by advance regeneration and pre-existing interfering plants present in the initial stand.

\section{Methods \\ Study area}

Data for this study came from the Black Brook district, a large private freehold (188 670 ha) owned by J.D. Irving Ltd., located in northwestern New Brunswick (47 $\left.18^{\prime} 44^{\prime \prime} \mathrm{N}, 67^{\circ} 42^{\prime} 38^{\prime \prime} \mathrm{W}\right)$. The climate is continental and temperate despite the proximity of the Atlantic Ocean. Temperatures of $25^{\circ} \mathrm{C}$ are frequent in the summer whereas average temperature in January is $-12^{\circ} \mathrm{C}$ - with extreme minimums of $-30^{\circ} \mathrm{C}$ to $-35^{\circ} \mathrm{C}$. Annual precipitations vary between 1000 and $1200 \mathrm{~mm}$, of which $33 \%$ falls as snow with cover lasting approximately 160 days (Environment Canada 2006). Primary lithology of the parent material is metamorphic quartzite and surface deposits are mainly compact tills. The terrain is composed of highlands that are part of the Appalachian range but have little influence on the overall climate. The study area is located on the Maritime Highlands Ecoregion and part of the Acadian Forest covering most of the Maritime provinces (Mosseler et al. 2003). The Acadian Forest includes red spruce (Picea rubens Sarg.), balsam fir (Abies balsamea [L.] Mill.), eastern hemlock (Tsuga canadensis [L.] Carr.), white pine, yellow birch, sugar maple (Acer saccharum Marsh.), red maple (Acer rubrum L.) and American beech ( $F a$ gus grandifolia Ehrh.). Proportions vary with local climate, soil fertility, terrain and disturbance (Erdle and Pollard 2002), forming a mosaic of hardwood, mixed and coniferous stands, on generally rich soils.

Studied stands are dominated by northern hardwoods (mainly sugar maple, American beech and yellow birch) sometimes in association with balsam fir and white spruce (Picea glauca [Moench] Voss). Some of these stands have received diameter-limit cuts in the 1950s and/or a harvest of the softwood component in the 1990s. Beech bark disease (Nectria coccinea var. faginata and N. galigena Bres.) has a great influence on American beech and has been present present in New Brunswick since 1930 (Houston 1975). The disease directly affects the health and longevity of mature beech (Houston 1994) and reduces stem quality. The disease seems to promote suckering among infected trees (Houston 2001), which indirectly hinders the development of more commercially desirable species like sugar maple and yellow birch (Hane 2003, Hane et al. 2003).

\section{Experiment design}

Thirty-seven stands were chosen to cover four silvicultural treatments used in tolerant hardwood stands and a 15-year range of time lapse after harvest. Time lapses were grouped in three classes, 1 to 5,6 to 10 and 11 to 15 years in order to represent a chronosequence. The four partial cutting systems were shelterwood, selection, patch and strip cuts all performed with feller-bunchers and grapple skidders. The design is not balanced, since strip cutting is no longer in use since 2000 and patch cutting was not tried in the area before 1995 (Table 1).

According to the company, selection and shelterwood cuts were performed in the winter to avoid damage to advance regeneration, to avoid wood staining due to heat and thus recover maximum value from quality sawlogs. Selection cutting was favoured in stands where tree quality and species composition was satisfactory. Although the intent was to improve the stands, structure was not specifically considered and no tree marking was performed. Felling operators were responsible for respecting the general prescription of the company to improve stand quality by removing any tree that would not make it through the next cutting cycle due to low vigour or decay. Shelterwood cutting was said to be favored in stands lacking either quality or desired tree species composition but with an adequate stocking of advance regeneration or saplings of desired species. Strip and patch cuts were favoured in stands where beech dominated the species composition and regeneration was deemed inadequate. Operations in strip and patch cuts were performed in the summer and fall in order to maximize soil disturbance. Patch cuts are approximately circular of $37 \mathrm{~m}$ average diameter $\left(1100 \mathrm{~m}^{2}\right)$ and strip cuts are of $35 \mathrm{~m}$ average width. All trees were cut inside and no trees were cut outside of strips and patches except for skid trails joining patches.

Information provided by the company about original stand and treatment was not always consistent. Although distinguishing between patch and strip cutting was easy, the distinction between selection and shelterwood cutting seems to have changed during the period when the treatments were applied (1989 to 2005). Some shelterwood cuts left so little residual basal area that they could easily be called seed-tree cuts, with great variation in residual stocking within a given stand. Alternatively, other stands were left with such a dense residual

Table 1. Number of replicates of natural regeneration sampling by treatment and lapse time after cutting in the Black Brook District

\begin{tabular}{lcccc}
\hline Type of cutting & $\begin{array}{c}\mathbf{1} \text { to } \mathbf{5} \\
\text { years }\end{array}$ & $\begin{array}{c}\mathbf{6} \text { to } \mathbf{1 0} \\
\text { years }\end{array}$ & $\begin{array}{c}\mathbf{1 1} \text { to } \mathbf{1 5} \\
\text { years }\end{array}$ & Control \\
\hline Selection & 3 & 5 & 3 & 2 \\
Shelterwood & 3 & 3 & 3 & 1 \\
Patch & 3 & 3 & - & - \\
Strip & - & 3 & 2 & 3 \\
\hline
\end{tabular}


forest cover that we concluded that they were the result of a selection cut. To alleviate these inconsistencies and uncertainties in the nature and intensity of treatments, in the absence of any preharvest data, we reclassified some stands based on their actual basal area and structure. This was deemed appropriate since residual diameter structure was a reversed-J shaped curve for all stands (Fig. 2) and since stands contained few trees of shade-intolerant species (Table 2). This assumes that the aim of selection was to regenerate new cohorts on a relatively short cutting cycle implying a high residual basal area and that of shelterwood cutting was to regenerate a new cohort uniformly throughout the new even-aged stand, by leaving a low basal area. The choice between the two treatments was mainly based on the amount of natural regeneration of desirable species.

We selected control stands based on proximity to treated stands and mature appearence on aerial photographs. Three control stands were chosen close to old (1995 and 1997) strip cuts, two were chosen close to selection cuts performed in 1999 and another one was chosen in close proximity to an old (1994) shelterwood cut. Residual stands in all treatments including controls exhibited a reverse $\mathrm{j}$-shaped diameter structure typical of uneven-aged stands (Fig. 2).

\section{Sampling}

The 37 stands were sampled during the summer of 2005, with two transects in each stand (Ribbens et al. 1994). To cover the range of light conditions and soil disturbance induced by cutting, each transect ran from edge to edge of cut (patch and strip cutting, Fig. 1a) or, from one side of a skid trail to same side of next trail (selection and shelterwood cutting, Fig. 1b) perpendicular to skid trails. Each transect was composed of 15 equidistant sample plots $1 \mathrm{~m}^{2}$ in area.

\section{Data - all stands}

Prism sweeps $\left(2 \mathrm{~m}^{2} /\right.$ ha per stem) were performed a few metres within stands at the end of each transect. In the absence of yield records, these four prism sweeps per stand allowed us to compare initial tree species composition and $\mathrm{DBH}$ structures between treatments lapse times after harvest.

A total of 1065 plots $\left(1 \mathrm{~m}^{2}\right)$ were sampled in June and July 2005, during which seedlings were tallied by species and height class $(<1 \mathrm{~m}, 1-2 \mathrm{~m},>2 \mathrm{~m})$. Percentage cover of various competing vegetation strata (herbs, graminoids, shrubs, trees) was
Table 2. Residual species proportions [\%] and total basal area for each treatment all time lapses after treatment combined in the Black Brook District

\begin{tabular}{lccccc}
\hline & Patch & Strip & Shelterwood & Selection & Control \\
\cline { 2 - 6 } & \multicolumn{5}{c}{ Species proportion (\% basal area) } \\
\hline Sugar maple & 48.8 & 54.0 & 65.2 & 54.4 & 44.3 \\
Yellow birch & 19.2 & 17.7 & 15.0 & 29.0 & 25.0 \\
American beech & 20.4 & 25.7 & 18.9 & 6.0 & 6.2 \\
Red maple & 6.3 & 0 & 0.4 & 6.8 & 2.2 \\
White birch & 1.9 & 0 & 0 & 0.4 & 1.8 \\
Conifers & 3.3 & 2.6 & 0.6 & 3.4 & 13.8 \\
Basal area (m 2 /ha) & 21.2 & 14.7 & 9.9 & 17.1 & 21.8 \\
\pm standard & 4.2 & 6.4 & 5.8 & 4.0 & 6.2 \\
deviation & & & & & \\
\hline
\end{tabular}
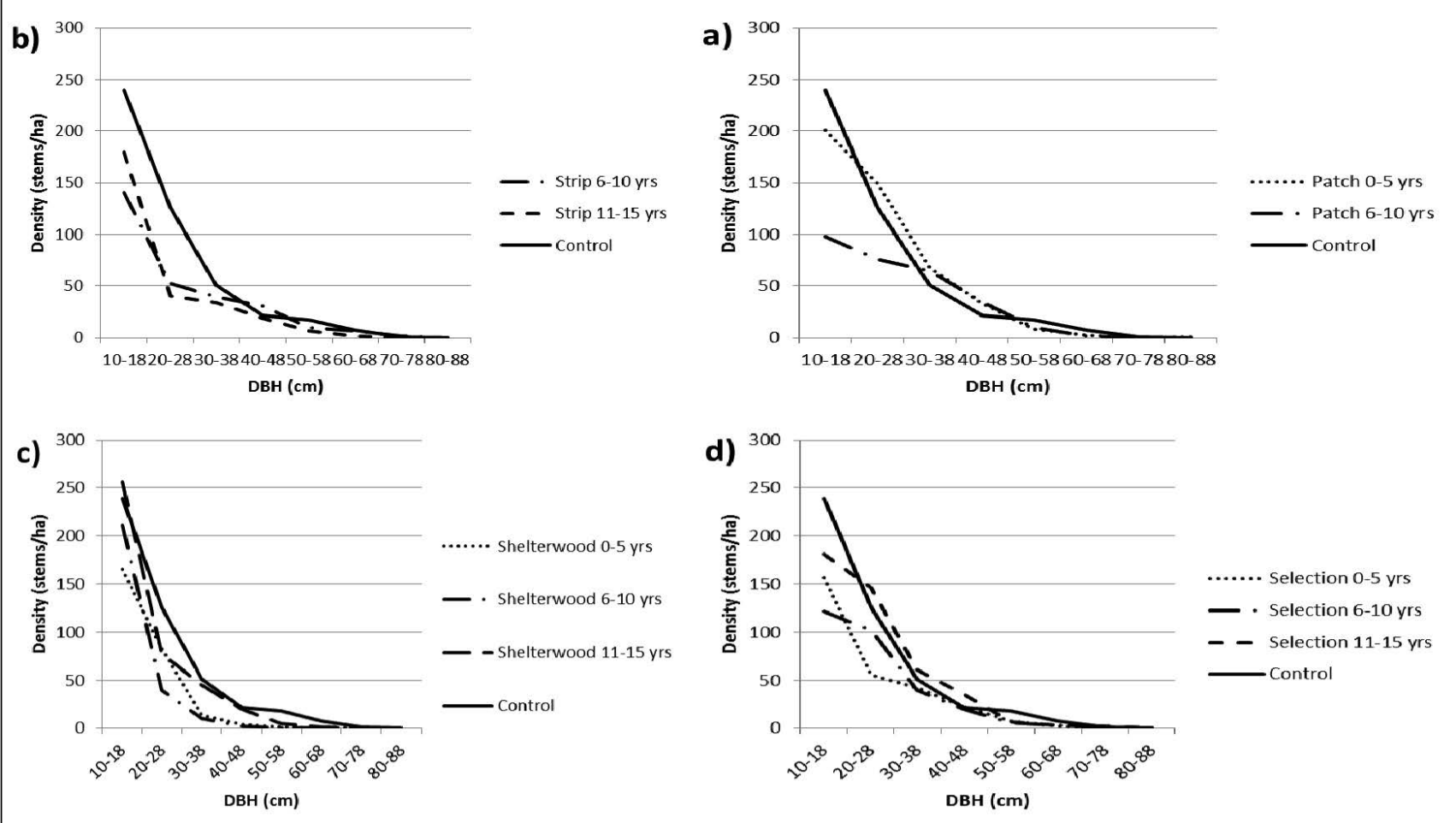

Fig. 2. Residual size structure of stands from prism points taken at different lapse time after a) patch cuts (around patches), b) strip cuts (between trips), c) shelterwood cuts and d) selection cuts in the Black Brook District. 
visually estimated $( \pm 5 \%)$. Average height of shrubs and tree regeneration $( \pm 10 \mathrm{~cm})$, thickness of soil organic layer $( \pm 1 \mathrm{~cm})$ and distance to the closest edge $( \pm 1 \mathrm{~m})$ were also measured at each plot.

\section{Data - one to five years after treatments}

In order to document the environmental conditions induced by the treatment, additionnal measurements were made in recently treated stands and in controls. These included canopy cover, distribution of substrates for germination and soil relative moisture. A digital hemispherical photograph of the canopy was taken at the center of each plot of stands that received shelterwood, selection and patch cuts between 2001 and 2005 and of control stands. These images were taken with an hemispherical $\left(183^{\circ}\right.$ viewing angle) lens. Geographic north was set at the top of each photograph and the centre at the zenith. The camera was set as close to the ground as possible thus detecting light interception by all competing vegetation strata interfering with seedling growth. Cover of each plot by different germination substrates was visually estimated $( \pm 5 \%)$. Substrates were: mineral soil, fresh wood, moss covered wood, decomposed dead wood recently exposed by forestry harvesting operations, organic matter, live moss, dead moss, animal disturbance (soil perturbation), live tree trunk and rock (LePage et al. 2000). Soil moisture was measured at three different locations in each plot using an electrical conductivity moisture meter (from DeltaT Device, Gaskin and Miller 1996). An average of the three measurements was used as an indicator of soil moisture for the plot.

\section{Data treatment}

Hemispherical photographs were treated using Gap Light Analyzer ver. 2.0 (Frazer et al. 1999), which allowed computation of a global light index of total light (direct + diffuse) reaching the understory. Images thus served as a proxy for light at the camera level. Tree species names were abreviated: sugar maple $(\mathrm{Sm})$, yellow birch $(Y b)$ and American beech $(B e)$. Variables (e.g., SmTotal, BeTotal, YbTotal) were generated representing the sum of seedling abundance of the three height classes of each species and another for the sum of seedling abundance of desirable species $(S m+Y b)$ of all sizes. Height of shrub competing vegetation being measured up to $4 \mathrm{~m}$, plots where shrubs were higher than $4.0 \mathrm{~m}$ were assigned a value of $4.1 \mathrm{~m}$. Stand-scale averages were computed.

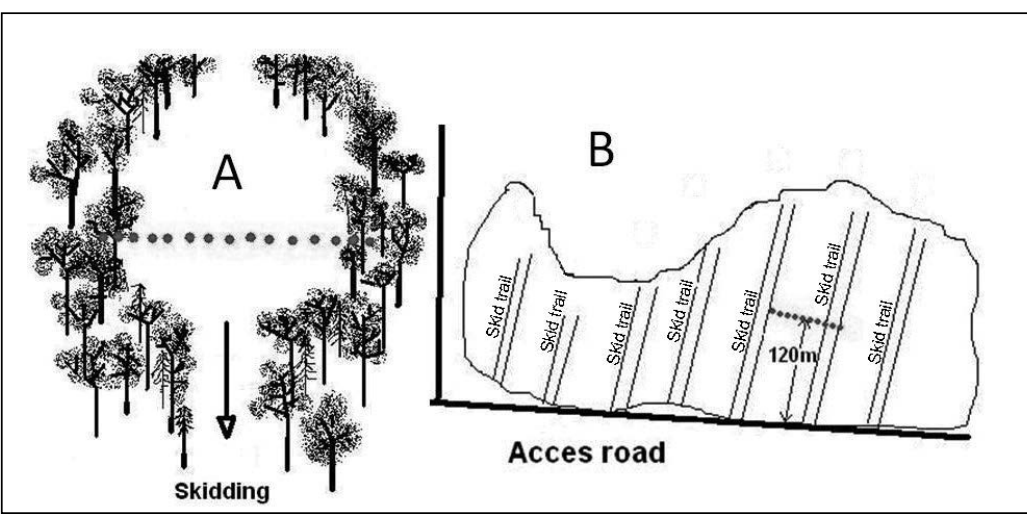

Fig. 1. Design of regeneration sampling transects $A$ ) in patch cuts and strip cuts and B) in selection cuts and shelterwood cuts in the Black Brook District.

\section{Data analyses}

Two-way ANOVAs were performed to describe and compare treatments and age classes with regards to soil moisture, proportion of mineral soil and decomposed wood substrates, global light index, species proportions in the residual stands and organic matter depth. ANOVAs were also done to compare seedling densities (stems per $\mathrm{m}^{2}$ ) of main species (sugar maple, American beech and yellow birch) between treatments. When ANOVAs were significant, the Duncan multiple range test was used to locate differences.

Simple linear regressions were performed to try to explain each dependent variable as a function of each independent variable at the stand scale. Residuals from these regressions were subject to a normality test (Shapiro-Wilk).

Multiple regressions were performed at the plot scale for all regeneration density variables as a function of the independent variables (\% herb cover, $\%$ shrub cover, mean shrub height and thickness of organic matter) measured in all classes of time since harvest and all treatments. Multiple regressions were also performed at the plot scale for regeneration density variables as a function of independent variables measured in all stands (\% cover herbs, \% cover shrubs, mean shrub height and thickness of organic matter) as well as those only measured in recent cuts and in control plots (\% transmitted light), mean soil moisture, O.M.\% (organic matter percent cover), D.W.\% (recently dead wood), R.W.\% (rotten wood), D.U.W.\% (recently exposed rotten wood), M.S.\% (mineral soil), L.M.\% (live moss), D.M.\% (dead moss), A.D.\% (animal disturbance), Tree\% (live tree trunk), R.O. (rock or parent material).

In patch and strip cuts, a simple linear regression model was tested between distance to edge and each regeneration density variable $(S m<1 m, S m 1-2 m, S m>2 m, B e<1 m$, Be $1-2 m$, $B e>2 m, Y b<1 m, Y b 1-2 m, Y b>2 m, S m+Y b)$. A normality test (Kolmogorov-Smirnov) was used to check for normality of regression residuals.

SPSS (version 15.0) for Windows was used for the statistical analyses.

\section{Results}

\section{Description of treatments}

We have no data to document pre-existing or residual conditions immediately after harvest in the sample stands that we used to evaluate regeneration responses. Yet our sample of recently cut stands suggests what conditions likely prevailed after the different treatments at Black Brook District. For example, less than five years after treatments, density in residual stands varies according to treatments (Table 2). Basal area is lower after shelterwood cutting than any other treatment. The proportion of yellow birch in residual stands is higher in selection than in uncut parts of patch or strip cuts, but not greatly different from shelterwood stands (Table 2). The proportion of red maple in the residual stand is also higher after selection cutting than after shelterwood cutting.

Less than five years after treatment, total transmitted light reaching the soil, although possibly affected by understory vegetation, was higher in patches (19\%) than in control stands (9\%). However, there was no significant 
difference between partial cuts (shelterwood and selection), between partial cuts and patch cuts or between partial cuts and controls (Table 3, Fig. 3).

Our sample of recently cut stands included assessment of tree species composition on plots with different lapse times after cutting. The Age $v s$. Treatment interaction is significant for the proportion of beech trees in the residual stand. The largest proportion of beech is observed around recently cut patches, in shelterwood cuts for the second age class ( 6 to 10 years) and is largely dominant beside strips for the third age class (Tables 3 and 4). Simple effects of both Age and Treatment were significant for the proportion of yellow birch in residual stands (Table 3). Overstory residual proportion of yellow birch was significantly lower in the third age class ( 11 to 15 years) than in the first (1 to 5 years)(Table 5 ). There was no other difference in tree species proportions between different age classes.

Thickness of organic matter was not significantly different between treatments $(P=0.878)$ nor between age classes $(P=0.890)$, the average being around $5 \mathrm{~cm}$ and $6 \mathrm{~cm}$. Less than five years post-harvest, mineral soil seedbed was more frequent $(P<0.0001$, Table 3$)$ after shelterwood cutting than after any other treatment (Table 6). Similarily, rotten wood was less frequent in control stands (Table 6). Soil moisture was higher after patch cuts than any other treatment $(P<0.0001)$.

\section{Effect of treatments on regeneration and competing vegetation}

Density of small $(<1 \mathrm{~m})$ beech and total density of beech regeneration are higher in patch cuts than any other treatment regardless of the time since treatment (Fig. 4). For yellow birch, shelterwood appears to lead to higher densities than other treatments, but this was not statistically significant (Fig. 4). Comparison of densities of other species showed no significant difference between treatments. Regeneration in commercially desirable species $(\mathrm{Sm}+\mathrm{Yb})$ was relatively good in all treatments, $\geq 40000$ stems per ha in all treatments, except in patches. There we found 28000 stems per ha (Fig. 4).

The relationship between regeneration densities and distance to closest edge in strip or patch cuts proved significant for sugar maple and beech $(S m<1 m, S m 1-2 m, B e<1 m, B e$ $>2 m$ and $S m+Y b)$. The simple linear regressions indicated a decrease in the number of seedlings with distance to an edge (Table 7). Given the width of strips and patches, distance to an edge ranged from zero to approximatively $18 \mathrm{~m}$.

An ANOVA showed significant variability of herb cover as a function of the different treatments $(17 \%$ to $72 \%, P<0.0001)$ (Fig. 5)
Table 3. Analyses of variance of various dependent variables as a function of treatment and lapse time after cutting in the Black Brook District

\begin{tabular}{llccc}
\hline Dependent variable & Source of variation & d.f. & Sum of squares & P \\
\hline \multirow{2}{*}{ \% transmitted light } & Treatment & 4 & 2993.289 & $<0.0001$ \\
& Error & 9 & 236.398 & \\
Proportion of species in & residual stand & & & \\
Sm & Treatment & 3 & 1627.583 & 0.355 \\
& Time & 2 & 2686.172 & 0.079 \\
& Treatment $\times$ Time & 4 & 3874.491 & 0.121 \\
Eb & Error & 26 & 12475.633 & \\
& Treatment & 3 & 1220.537 & 0.044 \\
& Time & 2 & 2105.950 & 0.002 \\
Be & Treatment $\times$ Time & 4 & 320.233 & 0.650 \\
& Error & 26 & 2818.000 & \\
& Treatment & 3 & 560.709 & 0.349 \\
& Time & 2 & 160.336 & 0.612 \\
$\mathrm{Bf}$ & Treatment $\times$ Time & 4 & 2149.078 & 0.034 \\
& Error & 26 & 2537.083 & \\
$\mathrm{Rm}$ & Treatment & 2 & 15.566 & 0.709 \\
& Time & 1 & 0.004 & 0.990 \\
& Treatment $\times$ Time & 1 & 8.004 & 0.558 \\
& Error & 10 & 218.417 & \\
& Treatment & 2 & 357.321 & 0.036 \\
& Time & 2 & 175.553 & 0.116 \\
& Treatment $\times$ Time & 1 & 52.513 & 0.213 \\
& Error & 5 & 128.667 & \\
& & &
\end{tabular}

Soil and vegetation

components

$\%$ cover of herbs

Treatment 3

4866.542

$<0.0001$

Time

2123.898

0.003

Treatment $\times$ Time

1168.660

0.121

3760.607

797.304

0.183

$\%$ cover of shrubs

Treatment

734.515

0.110

Treatment $\times$ Time

270.205

3961.526

Thickness of organic

Error

0.776

3.886

0.878

matter

\section{Soil moisture}

1.351

0.890

17.051

0.573

149.712

24925.898

5714.791

2046.667

15653.33

19733.600

Cover by rotten wood

Treatment

Error

Treatment

32421.400

$<0.0001$

$<0.0001$

$<0.0001$

Regeneration density

$\mathrm{Sm}<1 \mathrm{~m}$

Treatment

17.968

0.298

Time

1.962

0.811

28.643

0.219

$\mathrm{Yb}<1 \mathrm{~m}$

Time

120.544

Treatment

0.805

0.685

Time

3.370

0.060

Treatment $\times$ Time

0.756

0.840 
Table 3. Analyses of variance of various dependent variables as a function of treatment and lapse time after cutting in the Black Brook District (continued]

\begin{tabular}{llccc}
\hline Dependent variable & Source of variation & d.f. & Sum of squares & P \\
\hline $\mathrm{Be}<1 \mathrm{~m}$ & Treatment & 3 & 0.681 & 0.001 \\
& Time & 2 & 0.096 & 0.226 \\
& Treatment $\times$ Time & 4 & 0.875 & 0.001 \\
& Error & 26 & 0.796 & \\
Sm (all sizes) & Treatment & 3 & 21.262 & 0.336 \\
& Time & 2 & 0.842 & 0.932 \\
& Treatment $\times$ Time & 4 & 34.566 & 0.249 \\
Yb (all sizes) & Error & 26 & 155.874 & \\
& Treatment & 3 & 1.625 & 0.486 \\
& Time & 2 & 2.710 & 0.144 \\
& Treatment $\times$ Time & 4 & 0.941 & 0.832 \\
$\mathrm{Be}$ (all sizes) & Error & 26 & 16.837 & \\
& Treatment & 3 & 1.604 & 0.057 \\
& Time & 2 & 0.071 & 0.828 \\
& Treatment $\times$ Time & 4 & 1.360 & 0.158 \\
& Error & 26 & 4.896 & \\
Sm + Yb (all sizes) & Treatment & 3 & 24.365 & 0.273 \\
& Time & 2 & 0.900 & 0.927 \\
& Treatment $\times$ Time & 4 & 36.427 & 0.220 \\
& Error & 26 & 153.769 & \\
\hline
\end{tabular}

The presence of saplings of desirable species $(S m+Y b)$ was positively related to the proportion of these two species in the residual stand and negatively to herb cover. Beech regeneration was negatively affected by shrub cover (Table 8). Proportion of variance explained by these stand-scale regressions was small as $R^{2}$ varied from 0.11 to 0.30 .

Multiple regressions at the plot scale showed that less than five years after cutting, regeneration was affected negatively by the cover of herbs and of shrubs and by the thickness of organic matter. Analyses of combined age classes gave similar results (Table 9). Negative influences of shrub cover and organic matter thickness intensified when we removed the effects of light and distance to an edge from the multiple regression model. Proportion of variance explained by these plot-scale regressions was very small as $R^{2}$ varied from 0.01 to 0.1 .

Multiple regressions on recent treatments (one to five years) or controls, showed an important influence of germination substrates. The presence of live moss showed a negative correlation with sugar maple regeneration, but a positive effect on yellow birch. Transmitted light had a small

However, there was little variability in the cover of shrubs between treatments (Table 3). All treatments had a high cover of shrubs (45\% to 68\%, Fig. 5). Average height of tree regeneration was always greater than average shrub height.

\section{Explaining regeneration patterns}

Simple regressions, performed with data compiled at the stand scale, all lapse times after treatment combined, demonstrated that occurrence of sugar maple seedlings increases with the proportion of sugar maple trees in the canopy and decrease with herb cover. Presence of small yellow birch seedlings $(<1 \mathrm{~m})$ after cutting was negatively affected by cover and height of shrubs. negative effect on the tallest size classes of beech regeneration, but a more important positive effect on yellow birch $(<1 \mathrm{~m})$. Herb and shrub covers had a negative effect on most measured regeneration variables. Percent cover of live tree trunk was positively related to abundance of small beech regeneration. Rock was positively related to abundance of small seedlings of sugar maple. Dead wood was negatively related to regeneration of small seedlings of sugar maple. Soil moisture was negatively related to the presence of regeneration of both sugar maple and yellow birch regeneration (Table 10). Proportion of variance explained by these plotscale regressions was small as $R^{2}$ vary from 0.04 to 0.04 .

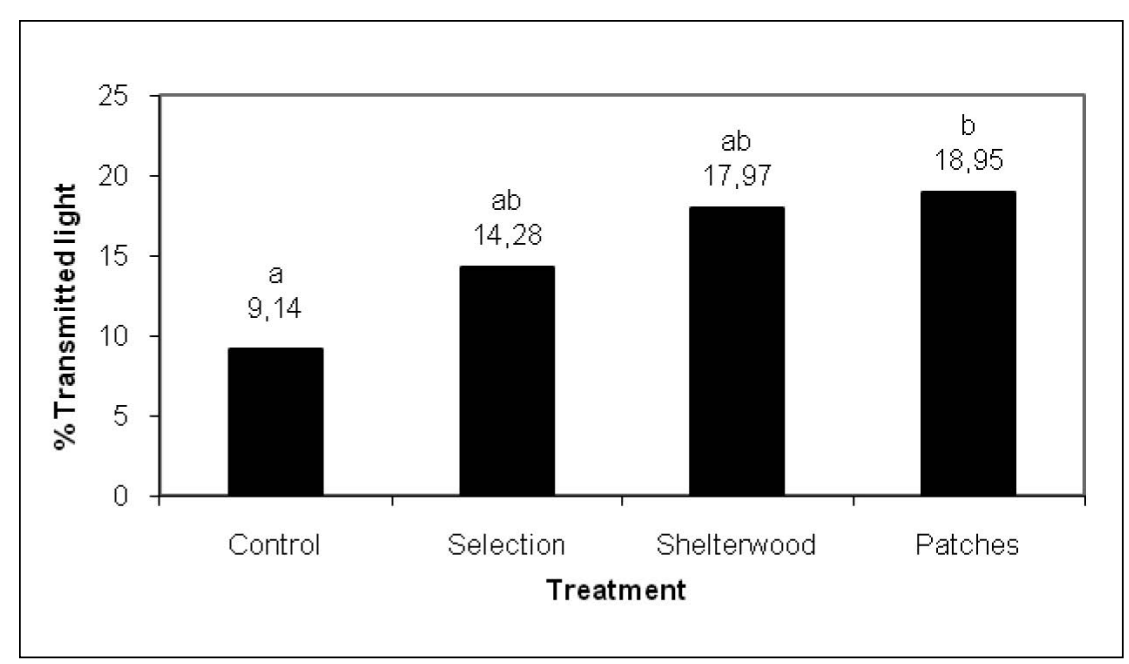

Fig. 3. Total transmitted light at ground level [\%] according to treatments within five years after cutting in the Black Brook District (Means with similar letter indicate non significant difference Duncan's multiple range test $\alpha=0,05$ ).

\section{Discussion}

\section{Regeneration abundance}

This study of natural regeneration at Black Brook is a retrospective comparison of silvicultural treatments rather than an experiment based on planned treatments. That limited our control over variability of conditions, such as tree species composition and size and density of understory vegetation. Interpretation of results must take this heterogeneity into account. Since pretreatment stand conditions were not documented, we relied on post-treatment measurements in more recently cut stands to judge the longer-term responses after different treatments to describe factors that likely affected regeneration, seedling emergence and survival. 
Table 4. Overstory residual proportion of beech in basal area (\%) by treatment and lapse time after cutting (in treated stands for selection and shelterwood cuttings and around patches and strips] in the Black Brook District

\begin{tabular}{lcccc}
\hline & \multicolumn{4}{c}{ Lapse time after cuttings } \\
\cline { 2 - 5 } Treatment & Control & $\begin{array}{c}\mathbf{1} \text { to } 5 \\
\text { years }\end{array}$ & $\begin{array}{c}\mathbf{6} \text { to } \mathbf{1 0} \\
\text { years }\end{array}$ & $\begin{array}{c}\mathbf{1 1} \text { to } \mathbf{1 5} \\
\text { years }\end{array}$ \\
\hline Control & 19.3 & - & - & - \\
Selection & - & 26.0 & 12.7 & 7.0 \\
Shelterwood & - & 19.5 & 39.5 & 17.0 \\
Patch & - & 27.3 & 14.0 & - \\
Strip & - & - & 13.0 & 45.0 \\
\hline
\end{tabular}

Table 5. Residual species proportions [\%] and total basal area for the different lapse times after cutting (all treatments combined, in treated stands for selection and shelterwood cuttings and around patches and strips] in the Black Brook District

\begin{tabular}{lcccc}
\hline $\begin{array}{l}\text { Lapse time } \\
\text { after cutting }\end{array}$ & $\begin{array}{c}\text { Sugar } \\
\text { maple } \\
\mathbf{( \% )}\end{array}$ & $\begin{array}{c}\text { Yellow } \\
\text { birch } \\
\mathbf{( \% )}\end{array}$ & $\begin{array}{c}\text { American } \\
\text { beech } \\
\mathbf{( \% )}\end{array}$ & $\begin{array}{c}\text { Total } \\
\text { basal area } \\
\left(\mathbf{m}^{\mathbf{2}} / \mathbf{h a}\right)\end{array}$ \\
\hline Control & 58.2 & 16.0 & 15.4 & 19.5 \\
1 to 5 years & 42.2 & 28.7 & 21.0 & 13.3 \\
6 to 10 years & 56.1 & 18.7 & 13.2 & 14.3 \\
11 to 15 years & 64.0 & 13.6 & 18.5 & 15.9 \\
\hline
\end{tabular}

\section{Effects of treatments}

As part of its management of uneven-aged tolerant hardwoods, J.D.Irving Ltd. used existing tree species composition and quality as a basis for determining how to manage a stand. Generally, it opted for: 1) patch and strip cutting in stands dominated by American beech and lacking adequate advance regeneration of other species; 2) shelterwood seed cutting when stands lacked favorable species, had limited overall quality, but adequate advance seedlings of desirable species; and 3) selection cutting for stands with desirable species and trees of good quality. These differences undoubtedly tempered post-cutting responses, complicating any direct assessment of treatment effects. Even so, the quantity of desirable seedlings varied little across treatments ( $\geq 40000$ seedlings/ha, Fig. 4 ), suggesting a potential for a successful outcome except after patch cutting. There, the abundance of American beech in the pre-cut stand likely favored development of that species to the detriment of others.

A beech response after the patch cutting would also be consistent with the general belief that any harvest in hardwood stands where beech is present in abundance favors regeneration of this species (Marquis et al. 1975, Kelty and Nyland 1981, Ostrofsky and McCormack 1986). Commonly, beech regenerates through root suckering after damage to roots during harvesting operations (Jones and Raynal 1986, Jones et al. 1989, Houston 2001). As patch cuts were performed in summer, root damage to beech was likely (Jones and Raynal 1988). In addition,
Table 6. Cover [\%] of germination substrates and soil moisture content showing significant differences between recently cut ( $0-5$ years] treatments in the Black Brook District

\begin{tabular}{lccc}
\hline Treatment & \% MS & \% RW & $\begin{array}{c}\text { \% Soil } \\
\text { moisture }\end{array}$ \\
\hline Control & 0.667 & 2.467 & 8.38 \\
Selection & 0.444 & 9.144 & 7.17 \\
Shelterwood & 4.444 & 7.111 & 8.34 \\
Patch & 1.556 & 8.944 & 11.00 \\
\hline
\end{tabular}

Note. MS : mineral soil, RW : Rotten wood.

Table 7. Regeneration density in the Black Brook District Simple linear regressions with distance to the closest edge in patch and strip cuts (all lapse times after cutting combined, $n=360$ )

\begin{tabular}{lccc}
\hline $\begin{array}{l}\text { Dependent } \\
\text { variable }\end{array}$ & $\mathbf{P}$ & $\mathbf{R}^{\mathbf{2}}$ & Coefficient \\
\hline$S m<1 \mathrm{~m}$ & $<0.001$ & 0.290 & -0.112 \\
$S m 1-2 \mathrm{~m}$ & 0.043 & 0.011 & -0.014 \\
$S m>2 \mathrm{~m}$ & n.s. & n.s. & n.s. \\
$Y b<1 \mathrm{~m}$ & n.s. & n.s. & n.s. \\
$Y b 1-2 m$ & n.s. & n.s. & n.s. \\
$Y b>2 m$ & n.s. & n.s. & n.s. \\
$S m+Y b$ & 0.001 & 0.029 & -0.129 \\
$B e<1 m$ & $<0.0001$ & 0.037 & -0.033 \\
$B e 1-2 m$ & n.s. & n.s. & n.s. \\
$B e>2 m$ & 0.044 & 0.011 & -0.008 \\
\hline
\end{tabular}

Note: n.s.: regression is not significant at threshold of 95\%; Sm: sugar maple; $Y b$ : yellow birch; $B e$ : American beech

increased temperature and light inside the patches also would favor root sucker development after cutting (Held 1983, Jones and Raynal 1988).

Shelterwood stands initially had less beech. Increased transmitted light after shelterwood seed cutting should have favoured less shade-tolerant species. Beech seedlings and suckers are relatively more abundant in the shelterwood stands than the strips. While unexpected due to the light levels and the presence of overwood, Hannah (1991) also observed more beech than desired species after high intensity of shelterwood cutting. We assume that mortality due to beech bark disease stimulated suckering that created an advance beech understory (Houston 1994, Krasny and DiGregorio 2001). This likely interfered with establishement of other species, as happened in the patches.

The proportion of yellow birch trees in residual stands after shelterwood seed cutting was relatively low (15\% compared to $20 \%$ to $30 \%$ in other treatments). This treatment generated the largest proportion of mineral soil substrate in more recently cut stands. Coupled with the long-distance dispersal of yellow birch, and adequate light, we expectetd greater amounts of yellow birch. In fact, Hannah (1991) observed the greatest quantity of yellow birch seedlings in the most intense shelterwood stands where only $40 \%$ of the canopy was left as shelter.

Possibly, shelterwood cuts at Black Brook (to $9 \mathrm{~m}^{2} / \mathrm{ha}$ ) may have been too intense to have environmental conditions 


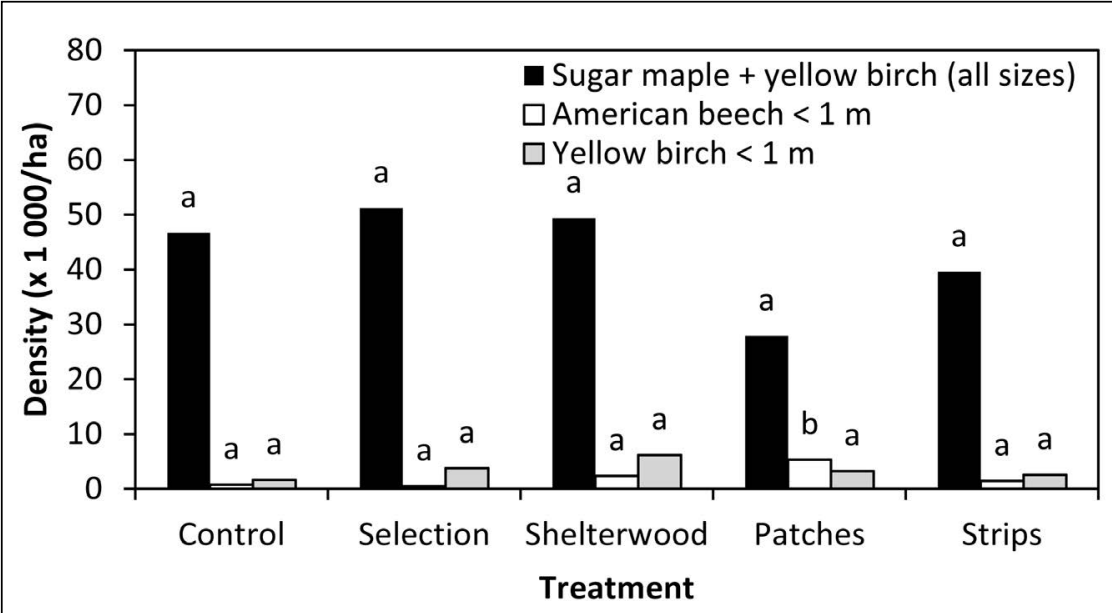

Fig. 4. Average density (stems per ha) of beech $(<1 \mathrm{~m}$ ), yellow birch $(<1 \mathrm{~m})$ and desired species (all size sugar maple and yellow birch) regeneration in the Black Brook District after various treatments all lapse times after treatment combined (Means with similar letter indicate non significant difference between treatments Duncan's multiple range test $\alpha=0.05)$.

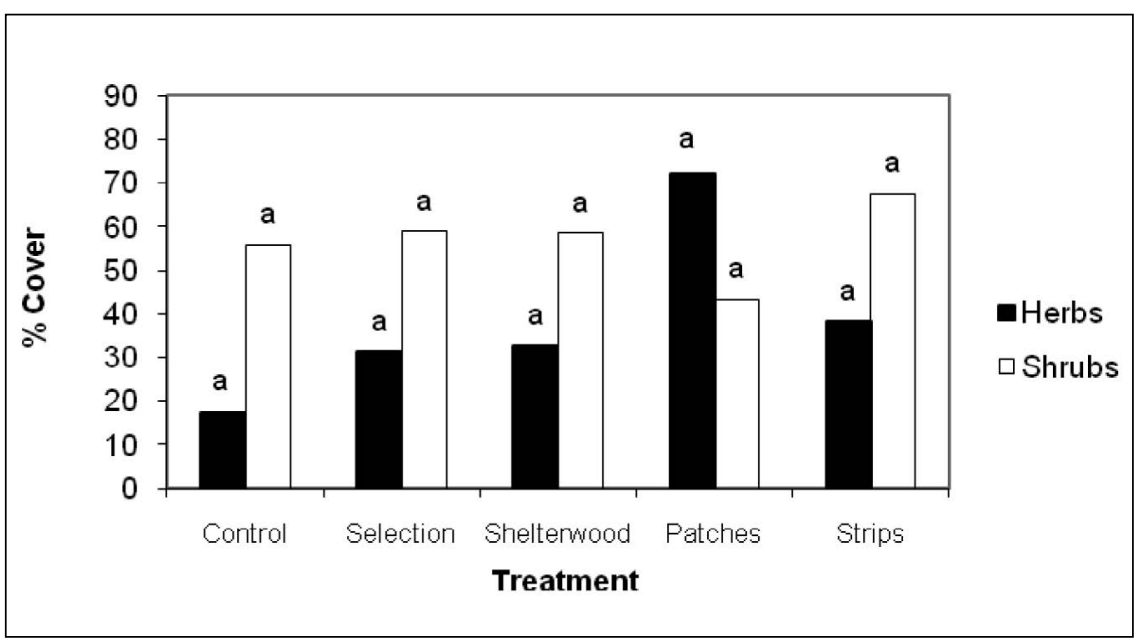

Fig. 5. Cover of competing herbs and shrubs after various treaments all lapse times after cutting combined. in the Black Brook District. Main shrub species: Rubus idaeus L., Acer spicatum Lamarck., Acer pensylvanicum L., Viburnum alnifolium Marsh., Cornus alternifolia L.f., Corylus cornuta Marshall and Lonicera canadensis W. Bartram ex Marshall. Main herb species: Oxalis montana, Maianthemum canadense, Clintonia borealis, Trientalis borealis, Aralia nudicaulis, Cornus canadensis, Streptopus roseus, Viola spp. Dryopteris spp. as used elsewhere. The residual basal area could have been as low as $12 \mathrm{~m}^{2} /$ ha, whereas more traditional selection cutting leaves $17 \mathrm{~m}^{2} /$ ha to regenerate tolerant species (Leak and Wilson 1958, Blum and Filip 1963, Crow and Metzger 1987). Targetted basal area often varies between 18 $\mathrm{m}^{2} /$ ha to $21 \mathrm{~m}^{2} /$ ha in Québec (Majcen et al. 1990, Guillemette and Bédard 2006), Ontario (Rice et al. 1998) and Nova Scotia (McGrath 2007). These lower densities increase the chance of regenerating a component of the less shade-tolerant species (Blum and Filip 1963, Crow and Metzger 1987). That may explain the success with yellow birch in our selection cut stands. Possibly, the residual densities used in the study area created environmental conditions more similar to those after traditional shelterwood seed cutting.

Control stands have the lowest amount of transmitted light, the lowest proportion of rotten wood available for germination and the least herb cover. The average stocking of $18.8 \mathrm{~m}^{2} /$ ha is probably similar to precut conditions of the treated stands that we examined. The proportion of beech in control plots is intermediate. Thus, we assume that they represent average preharvest conditions across the area. If so, our control plots may have lower beech stocking than those subject to patch or strip cutting. Advance regeneration in control plots was essentially of desirable species, possibly due to the moderate amount of beech in the stands.

\section{Effects of germination substrates}

Although we observed some plot-scale associations of yellow birch regeneration with mineral soil, partially rotten

significantly different from patches or strips. Hannah (1991), after testing different intensities of shelterwood cuts in similar stands, suggests that maintaining $60 \%$ to $80 \%$ of the forest cover is preferable for an adequate regeneration. According to Kelty and Nyland (1981) the control of beech (through herbicide used prior to seed cutting) as well as deer population and light management are important factors to insure adequate regeneration where deer browsing and heavy understory growth might preclude establishment of desirable species.

Selection cutting resulted in the highest density of seedlings of desired species, the smallest quantity of beech regeneration and the weakest competition by the herb stratum, other than the control plots. This treatment on Black Brook District may differ from single-tree selection system woody debris and live moss and other lesser-strength associations of sugar maple or beech with some seedbed types, the desired effect of site preparation or protection of advance regeneration was never acheived at the stand scale in any treatment. Moreover, knowing that beech root suckering may be strongly stimulated by root damage (Jones and Raynal 1988, Jones et al. 1989, Tubbs and Houston 1990, Houston 2001) and that the majority of beech roots are within a few centimetres of the soil surface (Hamilton 1955), it is probably a challenge to obtain favorable germination substrates for yellow birch while simultaneously limiting soil disturbance to control American beech. Clearcutting followed by planting (Yamasaki et al. 2008) or herbicides (Nelson and Wagner 2011) or regular shelterwood seed cutting with herbicide beech control (Kelty and Nyland 1981) are proposed as solutions to this problem. 
Table 8. Regeneration density in the Black Brook District - Stand-scale simple linear regressions with tree, shrub and herb vegetation strata independant variables (all lapse times after cutting and treatments combined, $n=37$ )

\begin{tabular}{lcccc}
\hline Dependent & Independent & $\boldsymbol{R}^{\mathbf{2}}$ & $\boldsymbol{P}$ & Coefficient \\
\hline Sm $<1 \mathrm{~m}$ & \% residual composition in Sm & 0.118 & 0.038 & 0.032 \\
& \% cover of herbs & 0.134 & 0.026 & -0.037 \\
$\mathrm{Sm}>2 \mathrm{~m}$ & \% residual composition in Sm & 0.121 & 0.035 & 0.003 \\
$\mathrm{Sm}$ (all sizes) & \% residual composition in Sm & 0.146 & 0.020 & 0.039 \\
& \% cover of herbs & 0.145 & 0.020 & -0.043 \\
$\mathrm{Yb}<1 \mathrm{~m}$ & \% cover of shrubs & 0.133 & 0.027 & -0.019 \\
& Height of shrubs & 0.150 & 0.018 & -0.446 \\
$\mathrm{Sm}+\mathrm{Yb}$ & \% residual composition in SM & 0.144 & 0.021 & 0.057 \\
all sizes $)$ & $\quad$ and Yb & & & \\
$\mathrm{Be}<1 \mathrm{~m}$ & \% cover of herb & 0.108 & 0.047 & -0.037 \\
$\mathrm{Be}>2 \mathrm{~m}$ & \% cover of herbs & 0.198 & 0.006 & 0.006 \\
$\mathrm{Be}$ (all sizes) & \%eight of shrubs & 0.306 & 0.000 & -0.011 \\
\hline
\end{tabular}

Note: Sm: sugar maple; $Y b$ : yellow birch; $B e$ : American beech

Table 9. Regeneration abundance in the Black Brook District - Plot-scale multiple regressions with ground conditions independent variables the for all lapse times after cutting (all treatments combined, $n=1065$ )

\begin{tabular}{|c|c|c|c|c|}
\hline $\begin{array}{l}\text { Dependant } \\
\text { variable }\end{array}$ & $P$ & $R^{2}$ & Independent variable & $\begin{array}{c}\text { Sign of } \\
\text { coefficient }\end{array}$ \\
\hline \multirow[t]{3}{*}{$S m<1 m$} & $<0.0001$ & 0.070 & $\%$ cover of herbs & - \\
\hline & & & $\%$ cover of shrubs & - \\
\hline & & & Thickness of O.M. & - \\
\hline \multirow[t]{2}{*}{$S m 1-2 m$} & $<0.0001$ & 0.061 & $\%$ cover of herbs & - \\
\hline & & & $\%$ cover of shrubs & - \\
\hline \multirow[t]{2}{*}{$S m>2 m$} & $<0.0001$ & 0.049 & $\%$ cover of herbs & - \\
\hline & & & $\%$ cover of shrubs & - \\
\hline \multirow[t]{2}{*}{$Y b<1 m$} & $<0.0001$ & 0.019 & $\%$ cover of shrubs & - \\
\hline & & & Thickness of O.M. & - \\
\hline \multirow[t]{2}{*}{$Y b 1-2 m$} & 0.009 & 0.009 & $\%$ cover of shrubs & - \\
\hline & & & Thickness of O.M. & - \\
\hline \multirow[t]{2}{*}{$Y b>2 m$} & $<0.0001$ & 0.018 & $\%$ cover of shrubs & - \\
\hline & & & Thickness of O.M. & - \\
\hline \multirow[t]{3}{*}{$S m+Y b$} & $<0.0001$ & 0.103 & $\%$ cover of herbs & - \\
\hline & & & $\%$ cover of shrubs & - \\
\hline & & & Thickness of O.M. & - \\
\hline \multirow[t]{2}{*}{$B e<1 m$} & $<0.0001$ & 0.031 & $\%$ cover of shrubs & - \\
\hline & & & Thickness of O.M. & - \\
\hline \multirow[t]{4}{*}{ Be $1-2 m$} & $<0.0001$ & 0.057 & $\%$ cover of shrubs & - \\
\hline & & & $\%$ cover of herbs & - \\
\hline & & & Thickness of O.M. & - \\
\hline & & & Height of shrubs & + \\
\hline
\end{tabular}

Note: Sm: sugar maple; $Y b$ : yellow birch; $B e$ : American beech. $P$ and $R^{2}$ values refer to the full model. Only independent variables with coefficients significanly different from 0 are presented.

Effects of competing vegetation

Based on observations in more recently cut stands, the shrub layer was likely well developed (>43\%) in all stands (Fig. 5) and this stratum may have a strong effect on light conditions (Beckage et al. 2000, Nyland et al. 2006) and consequently on growth (Beaudet and Messier 1998), survival (Kobe et al. 1995), and regeneration of desired species. The herb layer responded strongly to the openings in the more recently cut stands, then declined with time. This would reflect the relative shade intolerance of many forest herbs (Lavorel et al. 1997). Although variations between treatments are not significant, the herb layer shows a trend of increasing presence with the intensity of cutting (Fig. 5). Roberts (2004) obtained similar results along a gradient of natural disturbances. By responding so strongly to patch cuts, the herb layer may have contributed to the interference by small beech, to the detriment of yellow birch regeneration.

All species are affected negatively by the cover of competing vegetation (e.g. small beech and shrubs). By itself, the shrub layer may affect growth and early survival of tree seedlings by shading, whereas the herb layer probably limits regeneration mainly through the availability of germination substrates. The role of these two factors is largely recognized as determinent in natural regeneration and forest succession (Leak and Wilson 1958, Carson 1987, Martin and Hornbeck 1990, Pacala et al. 1994, Coates and Burton 1997, Beaudet and Messier 1998, Beckage et al. 2000). Even beech, the most shade-tolerant tree species, seems to be negatively affected by strong herbaceouos competition. Yet, as we lack data about their relative height to determine the degree that shrubs and herbs interfered with tree natural regeneration in the different sampled stands, we can only identify them as possible deterents to success.

\section{Conclusion and Recommendations}

Our results suggest that environmental conditions created by the silvicultural treatments performed in the Black Brook District did not differ enough to affect the species composition of natural regeneration, because of their high intensity and invasion by competing vegetation. On one side, selection and shelterwood cuts seemed too intense to restrict regeneration to tolerant species and, on the other side, competing vegetation decreased light availability after patch cutting. Variations in initial stand conditions between treatments as well as an evolution in forest operation methods with time within the company prevented us from analyzing the effect of time since treatments.

American beech regeneration, not desired due to low commercial value and infestation by the beech bark disease, proved to be very abundant after patch cutting. This 
Table 10. Abundance of regeneration in recent ( $0-5$ years] treatments in the Black Brook District - Plot scale multiple regressions with ground conditon independent variables [all treatments combined, $n=720$ ]

\begin{tabular}{|c|c|c|c|c|}
\hline $\begin{array}{l}\text { Dependent } \\
\text { variable }\end{array}$ & $P$ & $R^{2}$ & $\begin{array}{l}\text { Independent } \\
\text { variable }\end{array}$ & $\begin{array}{c}\text { Sign of } \\
\text { coefficient }\end{array}$ \\
\hline \multirow[t]{3}{*}{$S m<1 m$} & $<0.0001$ & 0.138 & $\begin{array}{l}\text { Soil moisture } \\
\text { dead wood \% }\end{array}$ & $\begin{array}{l}- \\
-\end{array}$ \\
\hline & & & Live moss $\%$ & - \\
\hline & & & Rock \% & + \\
\hline \multirow{4}{*}{$S m 1-2 m$} & $<0.0001$ & 0.090 & $\%$ cover of herbs & - \\
\hline & & & Live moss \% & - \\
\hline & & & Animal disturbance $\%$ & + \\
\hline & & & $\%$ shrubs & - \\
\hline \multirow[t]{4}{*}{$S m>2 m$} & $<0.0001$ & 0.087 & $\%$ cover of herbs & - \\
\hline & & & $\%$ shrubs & - \\
\hline & & & Live moss $\%$ & - \\
\hline & & & Dead moss \% & + \\
\hline \multirow[t]{5}{*}{$Y b<1 m$} & $<0.0001$ & 0.432 & Mineral soil \% & + \\
\hline & & & Dead moss \% & - \\
\hline & & & Transmitted light & + \\
\hline & & & live moss & + \\
\hline & & & Soil moisture & - \\
\hline$Y b>2 m$ & 0.015 & 0.017 & Animal disturbance $\%$ & + \\
\hline \multirow[t]{6}{*}{$S m+Y b$} & $<0.0001$ & 0.171 & Soil moisture & - \\
\hline & & & Mineral soil \% & + \\
\hline & & & Dead wood \% & - \\
\hline & & & Rock \% & + \\
\hline & & & $\%$ cover of shrubs & - \\
\hline & & & $\%$ herbs & - \\
\hline \multirow[t]{2}{*}{$B e<1 m$} & $<0.0001$ & 0.044 & Organic matter \% & + \\
\hline & & & Tree trunk \% & + \\
\hline \multirow[t]{2}{*}{ Be $1-2 m$} & $<0.0001$ & 0.066 & $\%$ cover of shrubs & - \\
\hline & & & Transmitted light & - \\
\hline \multirow[t]{4}{*}{$B e>2 m$} & $<0.0001$ & 0.100 & Height of shrubs & - \\
\hline & & & $\%$ herbs & - \\
\hline & & & $\%$ shrubs & - \\
\hline & & & Transmitted light & - \\
\hline
\end{tabular}

Note: $S m$ : sugar maple; $Y b$ : yellow birch; $B e$ : American beech. $P$ and $R 2$ values refer to the full model. Only independent variables with coefficients significanly different from 0 are presented.

resulted mainly from the initial condition of treated stands including advance beech in the understory rather than from environmental conditions created by the treatments. Abundant beech regeneration by root suckering was either stimulated by disturbance during skidding operations or pre-established. Contrary to expectations, shelterwood cutting performed in the winter provided the most adequate seedbed for regenerating yellow birch.

Based on observations from our study of regeneration responses at the Black Brook District, we recommend that when prescribing silvicultural treatments for uneven-aged tolerant hardwood stands, managers should consider that:

1. Areas with an understory of American beech, dense shrubs, or dense herbaceous plants require site preparation treatments to reduce interference either before removing the overstory or at the time of partial cutting;
2. Shelterwood seed cutting and selection cutting should leave a residual of $12 \mathrm{~m}^{2} / \mathrm{ha}$ and $17 \mathrm{~m}^{2} / \mathrm{ha}$, respectively, in seed trees uniformly distributed across the site.

\section{Acknowledgements}

The project was funded by Canada's Sustainable Forest Management Network, through a project entitled "Management implications of forest dynamics, succession, and habitat relationships under differing levels of silviculture in New Brunswick forests". We thank J.D. Irving Ltd. for accomodation in the field, land access and silvicultural data, T. Voisine and V. Laplante for field assistance. G. Adams, J.-M. Binot, D. Gravel, M. Rosen and S. Wyatt provided useful comments.

\section{References}

Allison, T.D., H.W. Art, F.E. Cunningham and R. Teed. 2003. Forty-two years of succession following strip clearcutting in a northern hardwoods forest in northwestern Massachusetts. Forest Ecology and Management 182: 285-301.

Anderson, H.W., B.D. Batchelor, C.M. Corbett, A.S. Corlett, D.T. Deugo, C.F. Husk and W.R. Wilson. 1990. A silvicultural guide for the tolerant hardwoods working group in Ontario. Ministry of Natural Resources, Ottawa.

Angers, V.A., C. Messier, M. Beaudet and A. Leduc. 2005. Comparing composition and structure in old-growth and harvested (selection and diameter-limit cuts) northern hardwood stands in Québec. Forest Ecology and Management 217: 275-293.

Baker, F.S. 1949. A revised tolerance table. Journal of Forestry 47: 179-181.

Beaudet, M. and C. Messier. 1998. Growth and morphological responses of yellow birch, sugar maple, and beech seedlings growing under a natural light gradient. Canadian Journal of Forest Research 28: 1007-1015.

Beaudet, M., C. Messier and C.D. Canham. 2002. Predictions of understorey light conditions in northern hardwood forests following parameterization, sensitive analysis, and tests of the SORTIE light model. Forest Ecology and Management 165(1/3): 235-248.

Beckage, B., J.S. Clark, B.D. Clinton and B.L. Haines. 2000. A long term study of tree seedling recruitment in southern Appalachian forests: The effects of canopy gaps and shrub understories. Canadian Journal of Forest Research 30: 1617-1631.

Bédard, S. and Z. Majcen. 2001. Ten-year response of sugar maple yellow birch - beech stands to selection cutting in Québec. Northern Journal of Applied Forestry 18(4): 119-126.

Bédard, S. and Z. Majcen. 2003. Growth following single-tree selection cutting in Québec northern hardwoods. The Forestry Chronicle 79(5): 898-905.

Blum, B.M. and S.M. Filip. 1963. A demonstration of four intensities of management in northern hardwoods (Research Paper NE-4). USDA Forest Service, Radnor, PA.

Boivin, J.L. 1985. Coupes par bandes dans des peuplements de feuillus - résultats après 14 ans. The Forestry Chronicle 61:229-232.

Buchman, R.G. 1983. Survival predictions for major Lake States tree species. Research paper NC-233. USDA Forest Service, St-Paul, MN.

Buchman, R.G. and E.L. Lentz. 1984. More Lake States tree survival predictions. Research Note NC-312. USDA Forest Service, St-Paul, MN.

Burns, R.M. and B.H. Honkala. 1990. Silvics of North America. Vol.2. Agricultural Handbook 654. USDA Forest Service, Washington, DC.

Carson, M. 1987. De l'apprentissage à la pratique en régénération naturelle des peuplements feuillus. Dans : Colloque - La régénération des essences feuillus de qualité (Hull 1987). Direction de la recherche et du développement, Gouvernement du Québec, MER, Québec.

Caspersen, J.P. and R.K. Kobe. 2001. Interspecific variation in sapling mortality in relation to growth and soil moisture. OIKOS 92(1): $160-168$. 
Clark, J.S. and Y. Ji. 1995. Fecundity and dispersal in plant populations: Implications for structure and diversity. The American Naturalist 146(1): 72-111.

Coates, K.D. and P.J. Burton. 1997. A gap-base approach for development of sylvicultural systems to address ecosystem management objectives. Forest Ecology and Management 99: 337-354.

Crow, T.R. and F.T. Metzger. 1987. Regeneration under selection system. In R.D. Nyland (ed.). Managing northern hardwoods. SUNY College of Environmental Science and Forestry, Syracuse, NY.

Environment Canada. 2006. Normales climatiques au Canada 1971-2000. [online]. Available at http://www.climat.meteo.ec.gc.ca/climate_normals/index_f.html.

Erdle, T. and J. Pollard. 2002. Are plantations changing the tree species composition of New Brunswick's forest? The Forestry Chronicle 78(6): 812-821.

Frazer, G.W., C.D. Canham and K.P. Lertzman. 1999. Gap Light Analyzer (GLA), Version 2.0: Imaging software to extract canopy structure and gap light transmission indices from true-color fisheye photographs, users manual and program documentation. Simon Fraser University, Burnaby, BC, and the Institute of Ecosystem Studies, Millbrook, NY.

Gaskin, G. and J. Miller. 1996. Measurement of soil water content using a simplified impedance measuring technique. Journal of Agricultural Engineering Resources 63: 153-160.

Gasser, D., C. Messier, M. Beaudet and M.J. Lechowicz. 2010. Sugar maple and yellow birch regeneration in response to canopy opening, liming and vegetation control in a temperate deciduous forest of Quebec. Forest Ecology and Management 259: 2006-2014.

Goldblum, D. 1997. The effects of tree fall gaps on understory vegetation in New York State. Journal of Vegetation Science 8: 125-132.

Guillemette, F. and S. BédardS. 2006. Sylviculture des peuplements à dominance de feuillus nobles au Québec. Direction de la Recherche Forestière, Gouvernement du Québec, MRN, Québec.

Hamilton, L.S. 1955. Silvicultural characteristics of American beech. Service Note no.13. USDA Forest Service, New York.

Hane, E.N. 2003. Indirect effects of beech bark disease on sugar maple seedling survival. Canadian Journal of Forest Research 33: 807-813.

Hane, E.N., S.P. Hamburg, A.L. Barber and J.A. Plaut. 2003. Phytotoxicity of American beech leaf leachate to sugar maple seedlings in a greenhouse experiment. Canadian Journal of Forest Research 33: 814-821.

Hannah, P.R. 1991. Regeneration of northern hardwoods in the northeast with the shelterwood method. Northern Journal of Applied Forestry 8: 99-104.

Held, M.E. 1983. Pattern of beech regeneration in the east-central United States. Bulletin of the Torrey Botanical Club 110:55-62.

Hoppes, W.G. 1988. Seedfall pattern of several species of bird-dispersed plants in an Illinois woodland. Ecology 69: 320-329.

Houston, D.R. 1975. Beech Bark Disease: the aftermath forests are structured for a new outbreak. Journal of Forestry 73: 660-664.

Houston, D.R. 1994. Major new tree disease epidemics: Beech bark disease. Annual Review of Phytopathology 32: 75-87.

Houston, D.R. 2001. Effect of harvesting regime on beech root sprouts and seedlings in a north-central Maine forest long affected by Beech Bark Disease. Research Paper NE-717. U.S. Department of Agriculture, Forest Service, Northeastern Research Station, Newtown Square, PA. $20 \mathrm{p}$.

Hurtt, G.C. and S.W. Pacala. 1995. The consequences of recruitment limitation: Reconciling chance, history, and competitive differences between plants. Journal of Theoretical Biology 176(1): 1-12.

Jenkins, M.A. and G.R. Parker. 2001. Woody species composition of disturbed forest in intermittent stream bottomlands of southern Indiana. Journal of Torrey Botanical Society 128: 165-175.

Johnson, J.A. 1984. Small-woodlot management by single-tree selection: 21-year results. Northern Journal of Applied Forestry 1: 69-71.

Johnson, W.C. 1988. Estimating dispersibility of Acer, Fraxinus and Tilia in fragmented landscapes from patterns of seedling establishment. Landscape Ecology 1: 175-187.
Jones, R.H., R.D. Nyland and D.J. Raynal. 1989. Response of American Beech regeneration to selection cutting of northern hardwoods in New York. Northern Journal of Applied Forestry 6: 34-36.

Jones, R.H. and D.J. Raynal. 1986. Spatial distribution and development of root sprouts in Fagus grandifolia (Fagaceae). American Journal of Botany 73: 1723-1731.

Jones, R.H. and D.J. Raynal. 1988. Root sprouting in American beech (Fagus grandifolia Ehrh.): Effects of root injury, root exposure and season. Forest Ecology and Management 25: 79-90.

Kelty, M.J., D.B. Kittredge, T. Kyker-Snowman and A.D. Leighton. 2003. The conversion of even-aged stands to uneven-aged structure in southern New England. Northern Journal of Applied Forestry 20(3): 109-116.

Kelty, M.J. and R.D. Nyland. 1981. Regeneration of Adirondack northern hardwoods by shelterwood cutting and control of deer density. Journal of Forestry. 79: 22-26.

Kimmins, J.P. 1997. Forest Ecology. $2^{\text {nd }}$ edition. Macmillan, New York. Kobe, R.K. and K.D. Coates. 1997. Models of sapling mortality as a function of growth to characterize interspecific variation in shade tolerance of eight tree species of north-western British Columbia. Canadian Journal of Forest Research 27: 227-236.

Kobe, R.K., S.W. Pacala, J.A. Silander Jr. and C.D. Canham. 1995. Juvenile tree survivorship as a component of shade tolerance. Ecological Applications 5: 517-532.

Krasny, M.E. and L.M. DiGregorio. 2001. Gap dynamics in Allegheny northern hardwood forests in the presence of beech bark disease and gypsy moth disturbances. Forest Ecology and Management 144: 265-274.

Lavorel, S., S. McIntyre, J. Landsberg and T.D.A. Forbes. 1997. Plant functional classifications: From general functional groups to specific groups of response to disturbance. Trends in Ecology and Evolution 12: 474-478.

Leak, W.B. 2005. Effects of small patch cutting on sugar maple regeneration in New Hampshire northern hardwoods. Northern Journal of Applied Forestry 22: 68-70.

Leak, W.B. and S.M. Filip. 1977. Thirty-eight years of group selection in New England northern hardwoods. Journal of Forestry 75: 641-643. Leak, W.B. and P.E. Sendak. 2002. Changes in species, grade, and structure over 48 years in a managed New England northern hardwood stand. Northern Applied Journal of Forestry 19: 25-27.

Leak, W.B. and R.W. Wilson Jr. 1958. Regeneration after cutting of old-growth northern hardwoods in New Hampshire. U.S. Department of Agriculture Forest Service, Northeastern Forest Experiment Station, Upper Darby, PA. Station Paper NE-103. 8 p.

LePage, P.H., C.D. Canham, K.D. Coates and P. Bartemucci. 2000. Seed abundance versus substrate limitation of seedling recruitment in northern temperate forests of British Columbia. Canadian Journal of Forest Research 30: 415-427.

Lessard, G., T. Rycabel, D. Blouin, M. Huot, R. Jobidon, C. Camiré and C. Olivier. 1999. L'utilisation des trouées dans la régénération des forêts du Québec. l'Aubelle, (Encart no. 128): 1-15.

Lorimer, C.G. 1981. Survival and growth of understory trees in oak forests of the Hudson Highlands, New York. Canadian Journal of Forest Research 11: 689-695.

Mader, S.F. and R.D. Nyland. 1984. Six year response of northern hardwoods to selection system. Northern Journal of Applied Forestry 1: 87-91

Majcen, Z. 1995. Résultats après 10 ans d'un essai de coupe de jardinage dans une érablière. Mémoire de recherche forestière no.122. Direction de la Recherche et du Développement, Gouvernement du Québec, MRN, Ste-Foy, QC.

Majcen, Z. 1996. Coupe de jardinage et coupe de succession dans cinq secteurs forestiers : Accroissement quinquennal en surface terrière et état de la régénération. Mémoire de recherche forestière no.70. Direction de la Recherche et du Développement, Gouvernement du Québec, MRN, Ste-Foy, QC. 
Majcen, Z. 1997. Coupe de jardinage et coupe de succession dans trois secteurs : Accroissement décennal en surface terrière et état de la régénération. Mémoire de recherche forestière no.129. Direction de la Recherche et du Développement, Gouvernement du Québec, MRN, Ste-Foy, QC.

Majcen, Z. and Y. Richard. 1992. Résultats après 5 ans d'un essai de coupe de jardinage dans une érablière. Canadian Journal of Forest Research 22: 1623-1629.

Majcen, Z. and Y. Richard. 1995. Coupe de jardinage dans six régions écologiques du Québec : Accroissement quinquennal en surface terrière. Mémoire de recherche no.120. Direction de la Recherche et du Développement, Gouvernement du Québec, MRN, Ste-Foy, QC.

Majcen, Z., Y. Richard, M. Ménard and Y. Grenier. 1990. Choix des tiges à marquer pour le jardinage des érablières inéquiennes. Guide technique. Mémoire de recherche forestière no.95. Direction de la Recherche et du Développement, Gouvernement du Québec, MER, QC.

Marks, P.L. 1974. The role of pin cherry (Prunus pensylvanica L.) in the maintenance of stability in northern hardwood ecosystems. Ecological Monographs 44(1): 73-88.

Marquis, D.A., T.J. Grisez, J.C. Bjorkhom and B.A. Roach. 1975. Interim guide to regeneration of Allegheny hardwoods. U.S. Dept. of Agriculture Forest Service, Northeastern Forest Experiment Station, Upper Darby, PA. Technical Report N.E.-19. 14 p.

Martin C.W. and J.W. Hornbeck. 1990. Regeneration after strip cuttings and block clearcutting in northern hardwoods. Northern Journal of Applied Forestry 7(2): 65-68.

McGrath, T. 2007. Tolerant Hardwood Management Guide. Nova Scotia Natural Resources, Truro, NS. Report FOR 2007-08.

Miller, G.W. 1995. Financial aspects of partial cuttings in Central Appalachian hardwoods. U.S. Dept. of Agriculture Forest Service, Northeastern Forest Experiment Station, Upper Darby, PA. Research Paper NE-673.

Mosseler, A., J.A. Lynds and J.E. Mayor. 2003. Old-growth forests of the Acadian Forest Region. Environmental Reviews 11: S47-S77.

Nelson, A.S. and R.G. Wagner. 2011. Improving the composition of beech-dominated northern hardwood understories in northern Maine. Northern Journal of Applied Forestry 28(4): 186-193.

Nyland, R.D. 2002. Silviculture. Concepts and application. The McGraw-Hill Companies, Inc. New York. 633 p.

Nyland, R.D., A.L. Bashant, K.K. Bohn and J.M. Verostek. 2006. Interference to hardwood regeneration in northeastern North America: Controlling effects of American beech, striped maple, and hobblebush. Northern Journal of Applied Forestry 23(2): 122-132.

Ostrofsky, W.D. and M.L. McCormack Jr. 1986. Silvicultural management of beech and the beech bark disease. Northern Journal of Applied Forestry 3: 89-91.

Pacala, S.W., C.D. Canham, J.A. Silander Jr. and R.K. Kobe. 1994. Sapling growth as a function of resources in a north temperate forest. Canadian Journal of Forest Research 24: 2172-2183.
Ribbens, E., J.A. Silander Jr. and S.W. Pacala. 1994. Seedling recruitment in forests: Calibrating models to predict patterns of tree seedling dispersion. Ecology 75: 1974-1806.

Rice, J., M. Woods and H. Anderson. 1998. Stand Stocking and Structure. Ch.6.0. In A silvicultural guide for the tolerant hardwood forest in Ontario. Ontario Ministry of Natural Resources. Queen's Printer for Ontario, Toronto, ON.

Roberge, M.R. 1987. Managing northern hardwoods by clearcutting $30 \mathrm{~m}$ wide strips: 10 year results. The Forestry Chronicle 63(3): 169-173.

Roberts, M.R. 2004. Response of the herbaceous layer to natural disturbance in North American forests. Canadian Journal of Botany 82: 1273-1283.

Runkle, J.R. 1982. Patterns of disturbance in some old-growth mesic forests of eastern North America. Ecology 63: 1533-1546.

Runkle, J.R. 1985. Disturbance regimes in temperate forest. Ch. 2 In S.T.A. Pickett and P.S. White (eds.). The ecology of natural disturbance and patch dynamics. Academic Press, New York.

Shugart, H.H. 1984. A theory of forest dynamics: The ecological implications of forest succession models. Springer-Verlap, Berlin.

Spurr, S.H. and B.V. Barnes. 1980. Forest Ecology ( $3^{\text {rd }}$ edition). John Wiley and Sons, New York.

Tierney, G.L. and T.J. Fahey. 1998. Soil seed bank dynamics of pin cherry in a northern hardwood forest, New Hampshire, USA. Canadian Journal of Forest Research 28: 1471-1480.

Tubbs, C.H. and D.R. Houston. 1990. Fagus grandifolia Ehrh. American beech. In R.M. Burns and B.H. Honkala (Technical coordinators). Silvics of North America Vol. 2. Hardwoods. USDA Forest Service, Washington, DC..

Ward, J.S. and G.R. Stephens. 1997. Survival and growth of yellow birch (Betula alleghaniensis) in southern New England. Canadian Journal of Forest Research 27: 156-165.

Whitmore, T.C. 1989. Canopy gaps and the two major groups of forest trees. Ecology 70: 536-538.

Wright, E.F., K.D. Coates, C.D. Canham and P. Bartemucci. 1998. Species variability in growth response to light across climatic regions in northwestern British Columbia. Canadian Journal of Forest Research 28: 871-886.

Yamasaki, S.H., S. Delagrange, F. Doyon, F. Lorenzetti, E. Forget. and T. Logan. 2008. Climate change adaptation strategies for the tolerant hardwood forests of eastern Canada. Report for the climate change Impacts and Adaptation Program. Natural Resources Canada. 78 p. 